\title{
Identifikasi pemahaman konsep dan penalaran ilmiah siswa SMA pada
}

\section{materi fluida statis}

\author{
Vicki Dian Prastiwi*, Parno, Hari Wisodo \\ Pascasarjana Prodi Pendidikan Fisika/ Universitas Negeri Malang, Jalan Semarang No. 5 Malang \\ * Penulis korespondensi, e-mail: diancki13@gmail.com
}

\begin{abstract}
Understanding of concepts and scientific reasoning are an important components of the Physics learning process. One of the importance of understanding the concept and scientific reasoning is facilitating students in understanding and applying concepts obtained for everyday life. This article aims to describe students' understanding of concept and scientific reasoning on Static Fluid topic. This research used mixed methods explanatory design with 31 students of class XII IPA who have obtained Fluid Static topic. The instruments used are 10 items of essay for conceptual comprehension and 20 multiple choice items justified for scientific reasoning with substantial reliability in order, ie 0.702 and 0.745 . The results show that students still have difficulty in understanding the concept of Fluid Static and still have a low scientific reasoning. Students' understanding of hydrostatic pressure sub topic is $18 \%$, Pascal's Law of $21 \%$, and Law Archimedes of $2.2 \%$. Scientific reasoning aspects used in this research are mass conservation reasoning, proportional reasoning, variable control, reasoning probability, correlation reasoning, and hypotetical deductive reasoning. Sequentially, the low level of students' scientific reasoning on Static Fluid material in each criterion is indicated by the following percentages: $24 \%, 40 \%, 34 \%$, $25 \%, 48 \%$, and $20 \%$.
\end{abstract}

Key Words: Fluid Static; Scientific Reasoning; Understanding of Concepts

\begin{abstract}
Abstrak: Pemahaman konsep dan penalaran ilmiah merupakan komponen penting dalam proses pembelajaran Fisika. Salah satu pentingnya dari pemahaman konsep dan penalaran ilmiah adalah dapat memberikan kemudahan siswa dalam memahami dan mengaplikasikan konsep yang diperoleh untuk kehidupan sehari-hari. Artikel ini bertujuan untuk mendeskripsikan pemahaman konsep dan penalaran ilmiah siswa pada materi Fluida Statis. Jenis penelitian ini menggunakan mixed methods explanatory design dengan subyek penelitian 31 siswa di kelas XII IPA yang telah memperoleh materi Fluida Statis. Instrumen yang digunakan dengan 10 butir soal esai untuk pemahaman konsep dan 20 butir soal pilihan ganda beralasan untuk penalaran ilmiah dengan besar reliabilitas secara berurutan, yaitu 0,702 dan 0,745. Hasil penelitian menunjukkan bahwa siswa masih mengalami kesulitan dalam memahami konsep Fluida Statis dan masih memiliki penalaran ilmiah yang rendah. Pemahaman konsep siswa pada sub materi tekanan hidrostatis sebesar 18\%, Hukum Pascal sebesar 21\%, dan Hukum Archimedes sebesar 2,2\%. Aspek penalaran ilmiah yang digunakan dalam penelitian ini, yaitu penalaran konservasi massa, penalaran proporsional, kontrol variabel, penalaran probabilitas, penalaran korelasi, dan hypotetical deductive reasoning. Secara berurutan rendahnya tingkat penalaran ilmiah siswa pada materi Fluida Statis di masing-masing kriteria, ditunjukkan dengan persentase sebagai berikut: $24 \%, 40 \%$, $34 \%, 25 \%, 48 \%$, dan $20 \%$.
\end{abstract}

Kata kunci: Fluida Statis; Pemahaman Konsep; Penalaran Ilmiah

How to Cite:

Prastiwi, V., Parno, P., \& Wisodo, H. (2018). Identifikasi pemahaman konsep dan penalaran ilmiah siswa SMA pada materi fluida statis. Momentum: Physics Education Journal, 2(2).

https://doi.org/10.21067/mpej.v1i1.2216

This is an open access article under the CC BY license (http://creativecommons.org/licenses/by-nc-nd/4.0/) https://doi.org/10.21067/mpej.v1i1.2216 


\section{Pendahuluan}

Fluida Statis merupakan salah satu materi yang banyak membuat kesalahan pemahaman konsep siswa. Banyaknya permasalahan yang membuat kesalahan pemahaman konsep inilah yang sangat berpengaruh pada penalaran ilmiah (Zimmerman, 2008). Oleh karena itu, penelitian dan pembelajaran yang berkaitan dengan materi Fluida Statis pada pemahaman konsep dan penalaran ilmiah telah banyak dilakukan. Beberapa penelitian tersebut antara lain telah dilakukan oleh S (Salma, 2015), (Yadaeni, 2016), dan (She, 2010). Hal ini menunjukkan bahwa Fisika merupakan salah satu ilmu yang mempelajari fenomena alam dan gelajanya dan memiliki permasalahan yang dapat diselesaikan dengan pemahaman konsep dasar dan bernalar siswa (Maulana, 2017). Pemahaman konsep dan penalaran ilmiah siswa dipengaruhi dari pengalaman siswa yang luas dan pengetahuan ilmiah yang telah dimiliki siswa sebelum pembelajaran dilakukan di sekolah (Smith \& Abell, 2008).

Pemahaman konsep pada materi Fluida Statis, yaitu kemampuan siswa dalam memahami dan menghubungkan fenomena-fenomena serta konsep-konsep berkaitan dengan Fluida Statis. Jika siswa telah memahami suatu konsep, maka siswa mampu menghubungkan antar konsep, menyimpulkan, dan menerapkan pengetahuan dalam kehidupan sehari-hari (Barron, Darling, \& Linda, 2008). Pada proses belajar, permasalahan yang berkaitan dengan pemahaman konsep ini masih sering terjadi di berbagai materi Fisika.

Permasalahan dalam pemahaman konsep yang berkaitan dengan pemahaman yang tidak sesuai dengan prinsip Fisika disebut miskonsepsi (Docktor \& Mester , 2014). Miskonsepsi jika tidak segera diatasi akan mengakibatkan kesulitan siswa dalam menyampaikan argumentasi, berpengaruh pada pengetahuan selanjutnya, dan juga hasil belajar siswa (NRC, 2000). Pemahaman konsep inilah yang akan mempengaruhi penalaran ilmiah yang merupakan kunci efektif dalam pembelajaran. (Colleta, Philips, Savinainen, \& Steinert, 2008) penelitian sebelumnya menyatakan bahwa penalaran ilmiah merupakan salah satu faktor dalam bidang sains dan Fisika yang mempengaruhi prestasi belajar siswa. Penalaran ilmiah juga berperan saat siswa menyelesaikan masalah Fisika (Moore \& Rubbo, 2012). Beberapa cara untuk mengatasi berbagai permasalahan berkaitan dengan miskonsepsi dapat dilakukan saat proses belajar berlangsung. Salah satu caranya adalah pada saat pemelajaran perlu adanya perencanaan (Lucey \& Norton, 2011).

Miskonsepsi dapat diatasi dengan cara mengidentifikasi kesalahan pemahaman yang terjadi pada siswa melalui pembelajaran yang melihat berbagai kesulitan yang dialami siswa (Gottheiner \& Siegel, 2012). Selain itu ketika ingin memperbaiki atau membangun penjelasan dapat menggunakan prinsip ilmiah sebagai pendukung dalam menjelaskan perbedaan fenomena dan membangun pemahaman yang mendalam, sehingga siswa akan mampu memahami konsep secara mendalam (Mcneill \& Krajcik, 2008). Beberapa penelitian yang berkaitan dengan miskonsepsi pada materi Fluida Statis diantaranya (Goszweski, Moyer, \& Bazan, 2012) dan (Wagner, Carbone, \& Lindow, 2013). Beberapa kesalahan pemahaman siswa pada materi Fluida Statis, antara lain (1) semakin banyak fluida yang berada di atas suatu titik, semakin besar tekanan hidrostatis yang dialami titik tersebut (Loverude, Kautz, \& Heron, 2010); (Goszweski, Moyer, \& Bazan, 2012), (2) tekanan fluida di ruang tertutup lebih besar daripada tekanan pada ruang terbuka meskipun kedua bejana tersebut saling berhubungan (Goszweski, Moyer, \& Bazan, 2012), (3) besar gaya angkat yang terjadi pada benda berbanding terbalik dengan besar massa jenis zat cair yang digunakan (Utami, 2014). Berbagai miskonsepsi inilah yang mengakibatkan siswa belum mampu mengatasi permasalahan, menyampaikan argumentasi, dan berpengaruh pada hasil belajar siswa pada materi Fluida Statis. Pengaruh yang diakibatkan oleh miskonsepsi inilah yang berkaitan dengan kemampuan penalaran ilmiah siswa.

Penalaran ilmiah merupakan kemampuan untuk menyimpulkan yang didasarkan dari bukti atau faktafakta yang ada. Oleh karena itu, penalaran ilmiah sangat berhubungan dengan proses pengumpulan data dan praktik ilmiah (Koenig, Schen, \& Bao, 2012). Permasalahan yang berhubungan dengan penalaran ilmiah akan membawa dampak pada kemampuan belajar siswa yang lain.

Penelitian yang dilakukan oleh (Khan \& Ullah, 2010) menyatakan bahwa jika kemampuan penalaran ilmiah siswa rendah, maka siswa akan mengalami kesulitan dalam menyelesaikan permasalahan Fisika. 
Penalaran ilmiah akan mendukung pemahaman konsep dan kinerja pada konten Fisika (Steinberg \& Cornier, 2013). Dalam Lawson Classroom Test of Scientific Reasoning (LCTSR) ada enam penalaran ilmiah, yaitu penalaran konservasi massa, penalaran proporsional, kontrol variabel, penalaran probabilitas, penalaran korelasi, dan hypotetical deductive reasoning.

Tujuan penelitian ini adalah untuk mendeskripsikan pemahaman konsep dan penalaran ilmiah siswa pada materi Fluida Statis. Deskripsi ini akan memberikan informasi tingkat pemahaman konsep dan penalaran ilmiah siswa. Disertai dengan hasil hasil wawancara yang menguatkan informasi tentang rendahnya tingkat pemahaman konsep dan penalaran ilmiah siswa. Tingkat pemahaman konsep dan penalaran ilmiah yang masih rendah perlu medapatkan perhatian khusus dalam proses pembelajaran Fisika, karena kedua variabel ini akan sangat berpengaruh dalam proses pembelajaran.

\section{Metode}

Prosedur penelitian dilakukan dengan mixed methods explanatory design, yang terdiri dari tahap analisis secara kuantitatif yang dilanjutkan dengan tahap kualitatif. Tahap kuantitatif, yaitu dengan menganalisis jawaban siswa pada masing-masing sub materi untuk melihat persentase pemahaman konsep dan menganalisis aspek sesuai dengan penalaran ilmiah. Tahap selanjutnya adalah kualitatif, yang dilakukan untuk mendukung analisis kuantitatif. Tahap kualitatif dilakukan dengan cara memberikan pertanyaanpertanyaan yang berkaitan dengan permasalahan yang ditemukan dalam tahap kuantitatif. Hasil analisis pada masing-masing variabel, dilakukan dengan langkah sebagai berikut (Cresswell \& Clark, 2007).

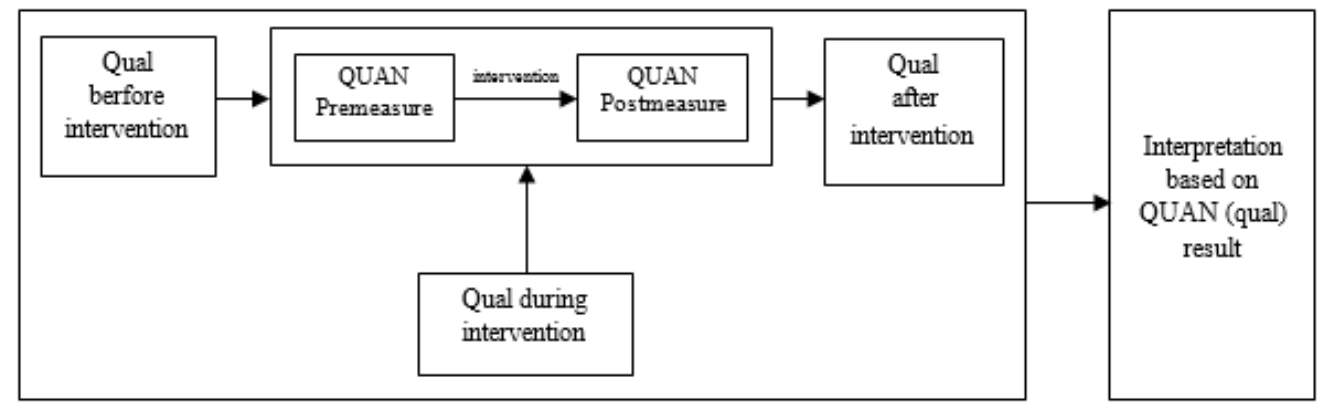

Gambar 1. Metode Penelitian

Penelitian ini dilakukan di kelas XII IPA yang telah memperoleh materi Fluida Statis sebanyak 31 siswa di SMA Negeri 7 Malang. Instrumen yang digunakan adalah 10 butir soal esai untuk pemahaman konsep dan 20 butir soal pilihan ganda beralasan untuk penalaran ilmiah. Soal terdiri dari materi Fluida Statis sub materi tekanan hidrostatis, Hukum Pascal, dan Hukum Archimedes yang diambil dari penelitian sebelumnya oleh (Dewi, 2017) dengan besar reliabilitas secara berurutan, yaitu 0,702 dan 0,745.

Hasil pemahaman konsep akan dikriteriakan menjadi empat, yaitu paham konsep (PK), paham sebagian (PS), spesifik miskonsepsi (SM), dan tidak paham (TP), sedangkan penalaran ilmiah akan dilihat berdasarkan pola penalaran, yaitu penalaran konservasi massa, penalaran proporsional, kontrol variabel, penalaran probabilitas, penalaran korelasi, dan hypotetical deductive reasoning.

\section{Hasil dan Pembahasan}

Penelitian ini menggunakan instrumen pemahaman konsep dan penalaran ilmiah yang telah digunakan oleh penelitian sebelumnya dengan nilai reliabilitas secara berurutan 0,702 dan 0,745 sebagai berikut. 
Tabel 1. Reliabilitas Instrumen Pemahaman Konsep

\begin{tabular}{lc}
\hline Cronbach's Alpha & N of items \\
\hline 0,702 & 10 \\
\hline
\end{tabular}

Data diolah, 2017

Berdasarkan Tabel 1 menunjukkan bahwa instrumen pemahaman konsep yang digunakan dengan 10 butir soal esai memiliki nilai reliabilitas maupun validitas yang baik, sehingga memenuhi syarat bahwa instrumen ini dapat digunakan untuk penelitian.

Tabel 2. Reliabilitas Instrumen Penalaran IImiah

\begin{tabular}{cc}
\hline Cronbach's Alpha & N of items \\
\hline 0,745 & 20 \\
\hline \multicolumn{2}{c}{ Data diolah, 2017}
\end{tabular}

Pada Tabel 2 juga telah diuji instrumen penalaran ilmiah dengan 20 butir soal pilihan ganda beralasan. Nilai reliabilitas menunjukkan nilai yang baik untuk digunakan sebagai alat penelitian.

Sesuai dengan metode penelitian yang telah dirancang, bahwa penelitian ini menggunakan dua tahapan. Tahapan pertama, yaitu dengan memberikan butir soal kepada siswa sebagai tahap kuantitatif. Analisis yang digunakan adalah melihat persentase dari setiap kriteria dan aspek yang telah ditetapkan. Persentase ini akan menunjukkan tingkat pemahaman konsep siswa dan penalaran ilmiah siswa berkaitan dengan materi Fluida Statis pada sub materi Tekanan Hidrostatis, Hukum Pascal, dan Hukum Archimedes. Selanjutnya tahapan kedua, yaitu memberikan beberapa pertanyaan yang berkaitan dengan berbagai permasalahan yang telah ditemukan pada tahapan pertama. Alasan-alasan yang diberikan oleh siswa inilah yang dapat memberikan gambaran utuh, pemahaman konsep maupun penalaran ilmiah siswa yang telah diperoleh dalam pembelajaran Fluida Statis. Analisis ini disebut analisis secara kualitatif yang akan menambahkan dan menguatkan deskripsi data kuantitatif.

Hasil penelitian digunakan untuk mengidentifikasi seberapa besar tingkat pemahaman konsep dan penalaran ilmiah siswa terhadap materi Fluida Statis yang akan digambarkan melalui hasil analisis dan hasil wawancara siswa. Berikut kondisi pemahaman konsep dan penalaran ilmiah siswa. Dapat dilihat pada Tabel 3

Tabel 3. Persentase Pemahaman konsep

\begin{tabular}{ccccc}
\hline \multirow{2}{*}{ Sub Materi } & \multicolumn{4}{c}{ Kriteria/ Persentase } \\
\cline { 2 - 5 } & PK & PS & SM & TP \\
\hline $\begin{array}{c}\text { Tekanan } \\
\text { Hidrostatis }\end{array}$ & $18 \%$ & $24 \%$ & $45 \%$ & $13 \%$ \\
Hukum Pascal & $20 \%$ & $6,5 \%$ & $64 \%$ & $9,7 \%$ \\
$\begin{array}{c}\text { Hukum } \\
\text { Archimedes }\end{array}$ & $2,2 \%$ & $32 \%$ & $0 \%$ & $65 \%$ \\
\hline & Data Diolah, 2018 & & \\
\hline
\end{tabular}


Berdasarkan Tabel 3. Persentase Pemahaman Konsep diperoleh hasil pemahaman konsep siswa pada sub materi secara berurutan pada tekanan hidrostatis, Hukum Pascal, dan Hukum Archimedes sebesar 18\%, $20 \%$, dan 2,2\%. Pemahaman konsep yang dialami siswa pada masing-masing sub materi dibedakan menjadi empat kriteria. Siswa yang memiliki paham konsep (PK) masih menunjukkan persentase yang sangat rendah pada setiap sub materi disetiap indikator. Rendahnya persentase ini menunjukkan bahwa secara keseluruhan memiliki tingkat siswa yang memiliki paham konsep hanya sebesar $40,2 \%$. Siswa yang memiliki kriteria tidak paham sebesar $87,7 \%$. Berdasarkan hasil ini menyatakan bahwa masih banyaknya siswa yang belum memahami Fluida Statis. Sesuai dengan penelitian yang dilakukan oleh (Rahmawati, Suparmi, \& Sunarno, 2017) bahwa masih banyaknya siswa yang mengalami miskonsepsi terhadap sub materi Hukum Archimedes. Indikator yang digunakan sesuai dengan permasalahan yang diperoleh dari penelitian yang telah dilakukan oleh peneliti sebelumnya, antara lain (1) Mengidentifikasi pengaruh kedalaman fluida terhadap tekanan hidrostatis, (2) Menerapkan perumusan Hukum Pascal dalam kehidupan sehari-hari, (3) Mengidentifikasi hubungan antara massa jenis fluida dengan besarnya gaya apung. Sebaliknya siswa yang mengalami spesifik miskonsepsi (SM) dan tidak paham (TP) memiliki persentase yang tinggi. Jika dirata-rata, siswa memiliki pemahaman konsep pada materi Fluida Statis masih sangat rendah sebesar 13,4 \%. Terutama pada sub materi Hukum Archimedes. Hal ini juga didukung dengan penelitian sebelumnya yang dilakukan oleh (Yadaeni, 2016) menyatakan bahwa pemahaman konsep siswa berkaitan dengan Fluida Statis tergolong rendah karena siswa masih belum dapat menyelesaikan masalah maupun soal-soal dengan baik. Permasalahan ini dapat diselesaikan dengan penggunaan tindak lanjut yang tepat. Misalnya dengan pemberian pembelajaran dengan praktikum akan mampu mereduksi miskonsepsi yang dialami siswa (Pratiwi \& Wasis, 2013). Selain itu sesuai dengan penelitian sebelumnya oleh (Chandra, Sutopo, \& Latifah, 2016) bahwa berbagai identifikasi ditemukan ketidakpahaman siswa ini karena adanya kesulitan menentukan prinsip atau faktor-faktor yang mempengaruhi dalam materi Fluida Statis.

Tabel 4. Persentase Penalaran IImiah

\begin{tabular}{ccccccc} 
Sub Materi & \multicolumn{6}{c}{ Pola Penalaran (\%) } \\
\cline { 2 - 7 } & 1 & 2 & 3 & 4 & 5 & 6 \\
\hline Tekanan & 8 & 11 & 10 & 9 & 12 & 6 \\
Hidrostatis & & & & & & \\
Hukum Pascal & 12 & 20 & 15 & 10 & 25 & 9 \\
Hukum & 4 & 9 & 9 & 6 & 11 & 5 \\
Archimedes & & & & & & \\
\hline
\end{tabular}

Data Diolah, 2018

Tabel 4. Persentase Penalaran IImiah memberikan informasi bahwa pada pola penalaran ilmiah sesuai dengan kriteria, yaitu (1) penalaran konservasi massa, (2) penalaran proporsional, (3) kontrol variabel, (4) penalaran probabilitas, (5) penalaran korelasi, dan (6) hypotetical deductive reasoning, memiliki persentase yang sangat rendah. Pola penalaran dengan urutan paling rendah adalah pola penalaran konservasi massa dan pola penalaran hypotetical deductive reasoning. Artinya siswa masing memiliki pola penalaran yang rendah untuk mengkonversikan massa dan memberika alasan atau hipotesis terhadap suatu permasalahan yang diberikan. Sesuai dengan penelitian yang dilakukan oleh (Wooley, Deal, \& all, 2018) menyatakan bahwa siswa menggunakan pengetahuan sebelumnya untuk menjawab pertanyaan bukan mengandalkan suatu informasi dalam soal atau permasalahan yang diberikan. Urutan sub materi yang memiliki penalaran ilmiah dari paling rendah, yaitu Hukum Archimedes, tekanan hidrostatis, dan Hukum Pascal. Hukum Archimedes memilki tingkat penalaran yang masih rendah dikarenakan konsep yang ada dalam pikiran siswa masih terdapat beberapa kesalahan.

Berdasarkan analisis kuantitatif pemahaman konsep dan penalaran ilmiah di atas, diketahui bahwa masih rendahnya hasil yang diperoleh pada masing-masing aspek dan sub materi. Hal ini didukung dengan 
hasil wawancara pada analisis kualitatif. Hasil wawancara menyatakan bahwa, siswa masih mengalami kesalahan pemahaman konsep berkaitan dengan faktor-faktor yang mempengaruhi sub materi tekanan hidrostatis, Hukum Pascal, dan Hukum Archimedes. Berikut hasil wawancara berkaitan dengan permasalahan yang ditemukan.

(1) Siswa masih menganggap bahwa tekanan pada fluida statis dipengaruhi oleh luas permukaan suatu benda karena adanya gaya gravitasi yang semakin besar pada wadah dan gravitasinya juga semakin besar

(2) Tekanan hidrostatis pada sebuah benda berbading lurus dengan ketinggian dan gravitasi

(3) Berat benda adalah satu-satunya faktor yang mempengaruhi tekanan hidrostatis

(4) Menganggap bahwa benda akan terasa ringan di air dikarenakan berat benda yang memang terasa ringan tanpa mengunakan konsep gaya apung

(5) Siswa belum dapat memamaparkan alasan benda dapat tenggelam, melayang, dan terapung

Kesalahan pemahaman ini berpengaruh pada pola pikir siswa, yaitu penalaran ilmiah yang digunakan untuk mencari fakta, praktik ilmiah, maupun menyimpulkan konsep yang diperoleh selama pembelajaran karena penalaran ilmiah merupakan suatu preditor yang baik dalam mencapai suati ilmu pengetahuan (Omer, Aysye, \& Zehra, 2015). Selain itu, pola pikir siswa yang berkaitan dengan penalaran ilmiah adalah pengetahuan yang belum didasarkan pada fakta dengan proses pencarian melalui penyelidikan atau praktik secara langsung (Piraksa, Srisawasdi, \& Koul, 2014).

\section{Simpulan}

Berdasarkan penjelasan hasil dan pembahasan yang telah diuraikan, dapat disimpulkan bahwa pemahaman konsep dan penalaran ilmiah siswa pada materi Fluida Statis masih sangat rendah. Hal ini dapat dilihat berdasarkan hasil persentase paham konsep (PK) siswa yang hanya $13,4 \%$ dan pola penalaran ilmiah yang secara keseluruhan masih 31,8\%. Pernyataan yang menyatakan bahwa pemahaman konsep merupakan salah satu komponen penting untuk mendukung penalaran ilmiah siswa adalah benar. Didukung dengan adanya hasil wawancara yang menjelaskan bahwa pemahaman konsep siswa pada materi Fluida Statis yang membawa penalaran ilmiah siswa menjadi rendah.

Dari hasil dan pembahasan dapat diartikan bahwa dengan persentase yang masih di bawah $50 \%$ ini menunjukkan siswa masih sangat membutuhkan proses pembelajaran Fisika yang dapat meningkatkan pemahaman konsep maupun penalaran ilmiah. Pentingnya siswa belajar aktif dan belajar secara konstekstual akan berpengaruh pada pemahaman konsep serta penalaran ilmiah yang nantinya dapat meningkatkan prestasi belajar Fisika siswa.

Adapun saran bagi penelitian selanjutnya adalah dalam mengidentifikasi pemahaman konsep siswa berkaitan dengan materi Fluida Statis dapat digunakan soal-soal berbentuk two tier agar siswa memiliki konsep yang lebih kuat. Selain itu untuk penalaran ilmiah dapat digunakan soal-soal pilihan ganda beralasan dengan berbagai tipe, misalnya pilihan ganda beralasan dengan alasan yang dijelaskan secara rinci ataupun dapat menggunakan soal esai. Hal ini dimaksudkan agar dapat melihat pemahaman konsep maupun penalaran ilmiah secara lebih jelas dan mendalam. Tidak hanya dengan pemberian soal yang bervariatif, namun dapat diselesaikan juga dengan memberikan tindakan yang tepat dalam proses belajar siswa. Misalnya saja dengan pemberian pembelajaran melalui laboratorium.

\section{Daftar Rujukan}

Barron , B., Darling, H., \& Linda. (2008). Teaching for Meaningful Learning: A Review of Research on Inquiry Based and Cooperative Learning. Edutopia.

Chandra, M., Sutopo, \& Latifah, E. (2016). Identifikasi Kesulitan Pemahaman Konsep Siswa pada Fluida Statis. Pros. Semnas Pend. IPA Pascasarjana UM, 339-350. 
Colleta, V., Philips, J., Savinainen, A., \& Steinert, J. (2008). Comment on "The effect of student" reasoning abilities on conceptual understanding and problem-solving skills in introductory mechanics. European Journal of Physics, 29 (5): 25-27.

Cresswell, J., \& Clark, V. (2007). Designing and conducting mixed methods research. California: Sage Publication.

Creswell, J., \& Clark, V. (2007). Designing and conducting mixed methods research. California: Sage Publications.

Dewi, I. (2017). Perubahan Konseptual dan Keterampilan Proses Sains Siswa dalam Pembelajaran Kolaboratif Berbantuan Real and Virtual Laboratory pada Materi Fluida Statis. Pascasarjana Universitas Negeri Malang.

Docktor, J., \& Mester , J. (2014). Synthesis of Discipline-Based Education Research in Physics. Physical Review Special Topics-Physics Education Research, 10 (2), 020119.

Goszweski, M., Moyer, A., \& Bazan, Z. (2012). Exploring Student Difficulties with Pressure in a Fluid. PERC Proceedings, Published by the American Under a Creative Commons Attribution.

Gottheiner, D., \& Siegel, M. (2012). Experienced Middle School Science Teachers Assessment Literacy: Investigating Knowledge of Student's Conceptions in Genetics and Ways to Shape Instruction. Journal of Science Teacher Education, 23 (5), 531-557.

Khan, W., \& Ullah, K. (2010). Scientific Reasoning: A Solution to the Problem of Intruction. International Journal of Basc \& Applied Sciences, 10 (3): 58-62.

Koenig, K., Schen, M., \& Bao, L. (2012). Explicity Targeting Pre service Teacher Scientific Reasoning Abilities and Understanding of Nature if Science through an Introductory Science Course. Science Educator, Vol 21 (2).

Loverude, M., Kautz, C., \& Heron, P. (2010). Identifying and Addressing Student Difficulties with Hydrostatic Pressure. American Journal of Physics, 78 (1): 75-85.

Lucey, T. A., \& Norton, E. A. (2011). Understandings of Retirement. Citizenship, Social and Economics Education, Volume 10 Number 12011.

Maulana, D. (2017). Analisis Kausalitas Pemahaman Konsep dengan Kemampuan Berpikir Kreatif Siswa pada Pemecahan Masalah Fisika. Jurnal Pendidikan Fisika dan Keilmuan (JPFK), 3 (1).

Mcneill, K., \& Krajcik, J. (2008). Inquiry and Scientific Explanations: Helping Students Use Evidence and reasoning. 121-134.

Moore, J., \& Rubbo, L. (2012). Scientific Reasoning Abilities of Nonscience Majors in Physics-Based Courses. American Pysical Society, 8 (1): 1-8.

Omer, A., Aysye, B., \& Zehra, T. (2015). The effect of gender and socio-economic status of students on their. Procedia_Social and Behavioral Sciences, 2753-2756.

Piraksa, C., Srisawasdi, N., \& Koul, R. (2014). Effect of Gender on Students' Scientific Reasoning Ability : A Case. Procedia-Social and Behavioral Sciences, 486-491.

Pratiwi, A., \& Wasis. (2013). PEMBELAJARAN DENGAN PRAKTIKUM SEDERHANA UNTUK MEREDUKSI MISKONSEPSI SISWA PADA MATERI FLUIDA STATIS DI KELAS XI SMA NEGERI 2 TUBAN. Jurnal Inovasi Pendidikan Fisika, Vol. 02 No. 03 Tahun 2013, 117 - 120.

Rahmawati, I. D., Suparmi, \& Sunarno, W. (2017). Students misconception about archimedes law. Madium: Seminar Nasional Pendidikan Fisika III 2017. 
Salma, V. M. (2015). Pengembangan E-diagnostic Test untuk Mengidentifikasi Pemahaman Konsep Fisika Siswa SMA Pada Pokok Bahasan Fluida. Semarang.

She, H. C. (2010). Bridging Scientific Reasoning and Conceptual Change. JOURNAL OF RESEARCH IN SCIENCE TEACHING, 91-119.

Smith, S., \& Abell, S. (2008). Assesing and Addresing Student Science Ideas. Science and Children. 45 (7): $72-$ 73.

Steinberg, J., \& Cornier, S. (2013). Understanding and Affecting Science Teacher Candidates Scientific Reasoning in Introductory Astrophysics. American Physical Society.

Utami. (2014). Remediasi Miskonsepsi Pada Fluida Statis Melalui Model Pembelajaran TGT Berbantuan Mind Mapping di SMA. Jurnal Pendidikan dan Pembelajaran, 3 (12): 1-12.

Wagner, D., Carbone, E., \& Lindow, A. (2013). Exploring Student Difficulties with Buoyancy. PERC Proceedings, Published by the American Association a Creative Commons Attribution.

Wooley, J. S., Deal, A. M., \& all, a. (2018). Undergraduate students demonstrate common false scientific. Elsevier, Thinking Skills and Creativity 27, 101-113.

Yadaeni, A. (2016). Studi Kesulitan Siswa dalam Menguasai Konsep Fluida Statis. Pros. Semnas Pend. IPA Pascasarjana UM, 59-64.

Zimmerman, C. (2008). The Development of Scientific Reasoning Skills: What Psycologists Contribute to an Understanding of Elementary Science Learning. Illionois State University. Illionois State University. 